\title{
Influence of Madrasah Head Leadership, Motivation and Madrasah Culture on Teacher Performance in Madrasah Aliyah Model 2 Medan
}

\author{
Amiruddin Siahaan ${ }^{1}$, Tien Rafida ${ }^{2}$, Khairunnisa Batubara ${ }^{3}$ \\ ${ }^{1,2}$ Universitas Islam Negeri Sumatera Utara, Indonesia \\ ${ }^{3}$ Postgraduate Program in Universitas Islam Negeri Sumatera Utara, Indonesia \\ amiruddinsiahaan@uinsu.ac.id
}

\begin{abstract}
The purpose of this study was to determine: (1) the influence of madrasa head leadership on teacher performance; (2) the effect of motivation on teacher performance (3) the influence of madrasa culture on teacher performance; (4) the influence of madrasa head leadership and motivation on teacher performance in Madrasah Aliyah Negeri 2 Model. The study was conducted at Madrasah Aliyah Negeri 2 Model located on Wiliem Iskandar no. 7A Medan. This research is a quantitative study with a population of 149 people and a sample of 109 people who were determined using the Slovin method. The results showed that (1) there was a positive and significant influence between the leadership of the madrasah head on teacher performance; (2) there is a positive and significant effect between motivation on teacher performance. (3) there is a positive and significant influence between madrasa culture on teacher performance. (4) there is a positive and significant influence between madrasah head leadership and motivation on teacher performance. (5) there is a positive and significant influence between the leadership of the madrasa headmaster and madrasa culture on teacher performance. (6) there is a positive and significant influence between motivation and madrasa culture on teacher performance. (7) there is a positive and significant influence between madrasah head leadership, motivation and madrasa culture together on teacher performance. Madrasah headship leadership, motivation and madrasa culture have an effect on teacher performance by $53.4 \%$ and the remaining $46.6 \%$ is determined by other factors.
\end{abstract}

Keywords

principal'sleadership, motivation, madrasa culture, teacher performance

\section{Introduction}

The teacher is one element in the field of education that must play an active role and position as a professional staff in accordance with the demands of an increasingly developing society. In this case the teacher is not solely as a teacher who transfers knowledge, but also as an educator who transfers values as well as a guide who gives direction and guides students in learning. A good teacher is certainly a professional teacher, a teacher who has 4 basic competencies, including: pedagogic, personality, social and professional. Ibrahim Bafadal in Amiruddin siahaan, et al (2017: 62) said that "Simply increasing teacher professional ability can be interpreted as an effort to help immature teachers who are unable to manage themselves become able to manage themselves, those who do not yet have the qualifications become qualified, who have not been accredited to be accredited.

Madrasah Aliyah educational institutions are one of the institutions that play an important role in preparing intelligent and comprehensive human resources in the future. To 
prepare for this requires a madrasa head who has a strong personality and qualified managerial competence. Anwar Prabu (2000: 22) provides an understanding that teacher performance as a set of real behaviors that are shown by a teacher when giving lessons to his students. The teacher's performance can be seen when he carries out teaching and learning interactions in class including his preparation both in the form of semester programs and teaching preparation.

Based on the previous opinion, the teacher's performance in this study is interpreted as the ability of teachers to carry out tasks on professional competence in the teaching and learning process.

Based on the observations and interviews of researchers with several teachers in the Medan 2 Aliyah Madrasah Medan Model, the results seen in the madrasa field experienced performance problems. It is suspected that the teacher's compulsion in teaching is still visible, this matter is indicated by the presence of teachers teaching fields of study that do not specialize, teachers come late to school, do not come to teach for reasons of illness, family affairs, parties and others.

Teachers are less creative in creating an interesting and comfortable learning atmosphere, this is characterized by a noisy and non-conducive classroom atmosphere. Some teachers are not able to compile their own syllabus, teacher motivation is also low, this can be seen from the presence of teachers who have not been able to use teaching aids or facilities that already exist.

If seen from the condition of Madrasah Aliyah Negeri 2 Medan Model that there are phenomena as follows: (a) There is still a conventional learning process. (b) There are still many teachers who have not been able to compile their own learning tools (c) School management is still ineffective in accordance with the demands of developing the implementation of school-based management completely and correctly due to various factors of teacher performance in schools is still relatively low, (d) The low performance of teachers can also be influenced by the lack of appreciation or motivation given by the principal to teachers who have good work performance. In this case the researchers suspect the low percentage of teacher performance in Madrasah Aliyah Negeri 2 Medan Model due to the leadership of the madrasa head who is not yet appropriate. Leadership according to Stoner in Wahjosumijdo (1999: 17) is a characteristic of a leader in guiding and directing a person and group of people to work sincerely in order to achieve organizational goals that have been determined in advance. For this reason, the headmaster of madrasa needs to improve how to lead a school or madrasa.

The researcher suspects that the leadership of the madrasa head is not appropriate to motivate teachers in carrying out their duties. According to Mulyasa (2012) motivation is the giving of a driving force that creates the excitement of one's work, so that they will cooperate, work effectively and be integrated with all efforts to achieve satisfaction. From the above understanding it can be stated that motivation is the provision of a stimulus or encouragement to increase employee morale and enthusiasm to work in accordance with what is desired by the leadership in an effort to achieve goals.

Based on the identification of the problems that have been described, illustrating the existence of several aspects that may be the cause of the emergence of problems that can affect teacher performance above, the scope of the problem of this study is limited to the influence of madrasa head leadership $\left(\mathrm{X}_{1}\right)$, motivation $\left(\mathrm{X}_{2}\right)$, and madrasa culture $\left(\mathrm{X}_{3}\right)$ on teacher performance (Y) in Madrasah Aliyah Negeri 2 Model Medan. 


\section{Review of Literature}

\subsection{Principal's Leadership}

Leadership which means being a leader of power of leading; the qualities of leader. (Hornby, 1990: 481) which means the strength or quality of someone in leading and directing what they lead to achieve goals. In Indonesian the leader is called head, leader, pioneer, coach, role model, guide, manager, mobilizer, chairman, head, guide, king, elders, and so on.

Understanding leadership according to Stoner in Wahjosumijdo (2001: 17) is a characteristic of a leader in guiding and directing a person and group of people to work sincerely in order to achieve organizational goals that have been determined in advance. Furthermore, according to Robbins in Wahjosumijdo (2001: 17) leadership is the ability to influence a group towards the achievement of certain goals.

Wahdjosumidjo (2001: 40), that the tasks that need to be considered by a leader are, (1) arousing the trust and loyalty of subordinates, (2) communicating ideas to others, (3) in various ways can influence others, (4) a person the leader is a great person who is admired and charming and is proud of his subordinates. Meanwhile, a leader's duty gives an indication that, (a) a leader functions as a person who is able to create change effectively in the group's appearance, (b) a leader functions to move others so that the person consciously knows what the leader wants.

\subsection{Motivation}

The word motivation comes from the Latin "movere" which means "to move" which is meant as "to move forward. Abdillah and A. Sulaiman. (2019) motivation is defined as "reinforcement of reason, inner power, drive". Gibson, Ivancevich and Donelly (1996) motivation is a concept that describes the forces that exist in individuals to initiate and direct behavior ".

Motivation is as a series of giving encouragement to someone to carry out actions to achieve the desired goals Sondang in Arif (2019). Motivation will cause impetus to someone who causes him to do certain actions to meet their needs. So work motivation is a psychological condition that encourages workers to make an effort to produce goods or services so that a goal can be achieved.

Robbins (2006: 218) suggests Herzberg's theory which argues that there are two extrinsic and intrinsic factors that influence a person's work. Extrensic factor is interpersonal between superiors and subordinates. Supervision techniques, administrative policies, working conditions and personal life. While the intrinsic factor (motivator) is a factor whose presence can lead to job satisfaction and increase individual work performance or results. In Herzberg's motivational theory, motivational factors include: achievement, recognition, responsibility, progress, work itself and the possibility of developing.

\subsection{School culture}

Every organization has a culture that can influence the attitudes and behavior of its members, including educational / school organizations. In cultural anthropology, the word culture is used as an abbreviation of the term culture, then the terms culture and culture are often interpreted the same. Owens in Wahyudi (2009: 142) defines culture as a view of life, values and norms that unite a society, as stated as follows: "Culture can be defined as shared philosophies, ideologies, values, assumptions, beliefs, expectations , attitudes, and norms that knit a community together ". While Edward B. Taylor (Linton, 1994: 18) argues that culture is a complex whole of knowledge, beliefs, arts, morals, law, customs, and other abilities and habits that humans acquire as members of society. Almost the same opinion was expressed 
by Koentjaraningrat in Wahyudi (2009: 143) that culture is a whole system of ideas, actions and results of human work in the context of people's lives which are made to belong to human beings through learning. While Tubss and Moss (2005: 237) interpret culture as a way of life that is developed and shared by a group of people and passed down from generation to generation.

Thus the school organizational culture is the values, beliefs, assumptions, hopes and norms, thoughts or ideas formed in the long journey of the school and is believed to be a guide in behaving for school members, especially in solving internal and external problems of the school.

\subsection{Teacher Performance}

The term "performance" comes from the word job performance or actual performance achieved by someone. In terminology, the notion of "performance" is "the work of the quality and quantity achieved by someone in carrying out their duties in accordance with the position or responsibility given to him" (Nawawi, 2001: 238).

While Siagian (2002: 327) argues that: "performance is a certain achievement which ultimately can be directly reflected from the outputs produced". The resulting output can be physical, this is confirmed by Nawawi (2001: 234) which mentions performance in terms of work, namely "a result of the implementation both physical and non-physical".

Performance is a picture of the level of achievement of the implementation of an activity in realizing the goals of the mission and vision of the organization (Siagian, 2002: 111). Furthermore Maler in Kusumastuti (2001: 75) states that: "performance as a performance that is as a person's success in carrying out a job. The difference in performance between individuals in work situations is due to differences in individual characteristics and different situations. "

Based on some of the above understanding, it can be concluded that performance is a real behavior that is displayed in a tangible result as an achievement and work achievement according to the indicator of achievement at a certain time.

Performance indicators are aspects that become a measure in assessing performance. According to Supardi (2014: 54) indicators of teacher performance can be monitored from the amount and quality of work produced by teachers including: knowledge, skills, placement systems, and units of experience variation, practical abilities, qualifications, work outcomes, and development.

\section{Research Method}

This research is located at Madrasah Aliyah Model 2 Medan. This type of research is quantitative research. The sampling technique is done randomly, data collection using research instruments, data analysis is quantitative / statistical in order to test the hypothesis that has been set. The population of this study is all teachers who are active in Madrasah Aliyah Negeri 2 Model Medan, amounting to 149 teachers. For this study, the sample of the study were teachers who were active in the madrasa. Taking the number of respondents using the Slovin formula (Husein Umar 2008: 78) determined by researchers with a percentage of $5 \%$. Based on this criterion the sample numbered 109 . The research data were collected using a Likert scale model questionnaire. The collected data were analyzed using correlation techniques and multiple regression with the help of the SPSS program. 


\section{Result and Discussion}

\subsection{First Hypothesis}

The first hypothesis states "There is a positive and significant influence of Madrasah Head Leadership on Teacher Performance". The following results of linear regression analysis using the SPSS 22.0 program.

Based on the results of calculations with the SPSS program shown in the table, the regression equation obtained between the Madrasah Head Leadership $\left(\mathrm{X}_{1}\right)$ variables to Teacher Performance $(\mathrm{Y})$ is $\hat{\mathrm{Y}}=30.533+0.300 \mathrm{X} 1$. The regression equation provides information that each change in Madrasah Principal Leadership value is one unit, it will affect teacher performance by 0.300 . The correlation coefficient is positive, it means there is a positive relationship between Madrasah Principal Leadership $\left(\mathrm{X}_{1}\right)$ and Teacher Performance (Y).

Based on the table, it was obtained t count of 4.690 where $t$ count $>t$ alpha table 0.05 (df = 149) and the significance (Sig.) Of 0.000. Based on this, it can be seen that $\mathrm{t}$ arithmetic 4,690 or the significance value (Sig.) $0,000<0.05$, so it can be concluded that the two variables have a significant regression relationship and there is an influence between $\mathrm{X}_{1}$ to $\mathrm{Y}$.

Madrasah leadship toward Teacher Performance by 35\%. This explains that the regression equation between Madrasah Principal Leadership $\left(\mathrm{X}_{1}\right)$ on Teacher Performance $(\mathrm{Y})$ is linear and significant with a magnitude of influence of $35 \%$ so that it can be accounted for as a tool in decision making in this study and in subsequent research. Given the influence given provides an assumption that the leadership of the madrasah head has an influence on improving teacher performance. The better the leadership of the madrasa head will be the better the teacher's performance.

\subsection{Second Hypothesisis}

The second hypothesis states "There is a positive and significant influence of Motivation on Teacher Performance". The following results of linear regression analysis using the SPSS 22.0 program.

Based on the results of calculations with the SPSS 22.0 program shown in the table, the regression equation obtained between the Motivation $\left(\mathrm{X}_{2}\right)$ variables against Teacher Performance $(\mathrm{Y})$ is $\hat{\mathrm{Y}}=30.533+0.218 \mathrm{X} 2$. The regression equation provides information that each change in the value of Motivation by one unit, it will affect teacher performance by 0.218 . The correlation coefficient is positive, it means there is a positive relationship between Motivation $\left(\mathrm{X}_{2}\right)$ and Teacher Performance $(\mathrm{Y})$.

Based on the table obtained t count of 2.567 where $t$ arithmetic $>\mathrm{T}$ alpha table 0.05 (df $=149$ ) and the significance (Sig.) Of 0.012. Based on this, it can be seen that the arithmetic 2.567 or the significance value (Sig.) $0.012<0.05$, so it can be concluded that the two variables have a significant regression relationship and there is an influence between $\mathrm{X} 2$ on Y.

The magnitude of the effect of Motivation on Teacher Performance by 23.6\%. This explains that the regression equation between Motivation $\left(\mathrm{X}_{2}\right)$ to Teacher Performance $(\mathrm{Y})$ is linear and significant with a large effect of $10.3 \%$ so that it can be accounted for as a tool in decision making in this study and in subsequent studies. Given the influence given provides an assumption that motivation has an influence on improving teacher performance. The better the motivation of the teacher, the better the teacher's performance will be.

This explains that the regression equation between Motivation $\left(\mathrm{X}_{2}\right)$ to Teacher Performance (Y) is linear and significant, so that it can be accounted for as a tool in decision making in this study and in subsequent research. Given the influence given gives an 
assumption that the higher the motivation of the teacher will have an influence on improving teacher performance. The better the motivation of the teacher in doing their duties and obligations, the better the teacher's performance will be.

\subsection{Third Hypothesis}

The second hypothesis states "There is a positive and significant influence of Madrasah Culture on Teacher Performance". The following results of linear regression analysis using the SPSS 22.0 program.

Based on the results of calculations with the SPSS 22.0 program shown in the table, the regression equation obtained between the Madrasah Culture $\left(\mathrm{X}_{3}\right)$ and Teacher Performance (Y) variables is $\hat{\mathrm{Y}}=30.533+0.270 \mathrm{X} 3$. The regression equation provides information that each change in the value of Madrasah Culture by one unit, it will affect teacher performance by 0.270 . Correlation coefficient is positive, it means there is a positive relationship between Madrasah Culture $\left(\mathrm{X}_{3}\right)$ and Teacher Performance (Y).

Based on the table, $t$ count is obtained where $t$ count $>t$ alpha table is $0.05(\mathrm{df}=149)$ and significance (Sig.) Is 0.002. Based on this, it can be seen that tcount 3226 or the significance value (Sig.) $0.002<0.05$, so it can be concluded that the two variables have a significant regression relationship and there is an influence between $\left(\mathrm{X}_{3}\right)$ to $\mathrm{Y}$.

The magnitude of the influence of Madrasa Culture on Teacher Performance by $42.3 \%$. This explains that the regression equation between Madrasah Culture $\left(\mathrm{X}_{3}\right)$ and Teacher Performance (Y) is linear and significant with a magnitude of $42.3 \%$ so that it can be accounted for as a tool in decision making in this study and in subsequent studies. Given the influence given gives an assumption that madrasa culture has an influence on improving teacher performance. The better the madrasa culture owned by the teacher, the better the teacher's performance will be.

This explains that the regression equation between Madrasah Culture $\left(\mathrm{X}_{3}\right)$ and Teacher Performance (Y) is linear and significant, so it can be accounted for as a tool in decision making in this study and in future research. With the influence given gives an assumption that the higher Madrasah Culture owned by the teacher will have an influence on improving teacher performance. The better the Madrasah Culture of the teacher in carrying out their duties and obligations, the better the teacher's performance will be.

\subsection{Fourth Hypothesis}

The first hypothesis states "There is a positive and significant influence between Madrasah Head Leadership and Motivation on Teacher Performance". The following results of linear regression analysis using the SPSS 22.0 program.

Based on the results of calculations with the SPSS program shown in the table, the regression equation obtained between the Madrasah Principal Leadership $\left(\mathrm{X}_{1}\right)$ and Motivation $\left(\mathrm{X}_{2}\right)$ variables to Teacher Performance $(\mathrm{Y})$ is $\hat{\mathrm{Y}}=30.533+0.300 \mathrm{X} 1+0.218 \mathrm{X} 2$. The regression equation provides information that each change in the value of Madrasah Principal Leadership and Motivation is one unit, it will affect the teacher's performance by 0.518. Correlation coefficient is positive, it means there is a positive relationship between Madrasah Head Leadership $\left(\mathrm{X}_{1}\right)$ and Motivation $\left(\mathrm{X}_{2}\right)$ on Teacher Performance $(\mathrm{Y})$.

Based on the table obtained $t$ count of 4,690 and 2,567 where $t$ count $>t$ alpha table 0.05 $(\mathrm{df}=149)$ and significance (Sig.) Of 0,000 and 0.012. Based on this, it can be seen that $\mathrm{t}$ arithmetic 4.690 and 2.567 or the significance value (Sig.) $0.002<0.05$, so it can be concluded that the three variables have a significant regression relationship and there is an influence between $\mathrm{X}_{1}$ and $\mathrm{X}_{2}$ on $\mathrm{Y}$. 
The magnitude of the influence of madrasa head leadership and motivation on Teacher Performance by $48.8 \%$. This explains that the regression equation between Madrasah Principal Leadership $\left(\mathrm{X}_{1}\right)$ and Motivation $\left(\mathrm{X}_{2}\right)$ on Teacher Performance $(\mathrm{Y})$ is linear and significant with $48.8 \%$ influence so that it can be accounted for as a tool in decision making in this study and in subsequent research. Given the influence given, it gives an assumption that the madrasah head's leadership and motivation have an influence on improving teacher performance. The better the leadership of the madrasah leader and the motivation of the teacher, the better the teacher's performance will be.

This study is in accordance with the competency standards of madrasah principals according to the Minister of National Education Regulation No. 28 of 2010 concerning the Assignment of Teachers as Principals / Madrasas, "Principals / Madrasas are teachers who are given additional duties to lead kindergarten / raudhotul athfal (TK / RA), extraordinary kindergarten (TKLB), elementary school /, madrasah ibtidaiyah (SD / MI), extraordinary elementary school (SDLB), junior high school / madrasah tsanawiyah (SMP / MTs), extraordinary junior high school (SMPLB), senior high school / madrasah aliyah (SMA / MA), vocational high school / madrasah aliyah vocational (SMK / MAK), or extraordinary high school (SMALB) which are not international standard schools (SBI) or which are not developed into international standard schools (SBI)".

One of the factors influencing teacher performance is teacher motivation, because teacher motivation is the basis for teachers to improve their performance in carrying out learning activities in madrasas and complete all the administration needed to carry out their duties. According to Dessler (2003: 302) motivation is the giving of a driving force that creates the excitement of one's work, so they want to work together, work effectively and be integrated with all efforts to achieve satisfaction. From the above understanding it can be stated that motivation is the provision of a stimulus or encouragement to increase employee morale and enthusiasm to work in accordance with what is desired by the leadership in an effort to achieve goals. The results showed a statistical influence of motivation on teacher performance based on the null hypothesis $\left(\mathrm{H}_{\mathrm{o}}\right)$ which states there was no positive influence of motivation $\left(\mathrm{X}_{2}\right)$ on teacher performance $(\mathrm{Y})$ against alternative hypotheses $(\mathrm{Ha})$ which stated there was a positive effect, the test was using regression analysis techniques. multiple. Hypothesis test results showed that the tcount was obtained at 2.567 and the significance value (Sig.) 0.012. Thus, Ho is rejected and $\mathrm{Hi}$ is accepted, which means that there is a positive and significant influence of motivation on teacher performance. The magnitude of the effect is shown by the coefficient of determination $\mathrm{R} 2$ ( $\mathrm{R}$ square) $=0.236$, which means that motivation influences teacher performance by $23.6 \%$ and the remaining $76.4 \%$ is determined by other factors.

The results showed statistics of the influence of madrasa culture on teacher performance based on the null hypothesis $\left(\mathrm{H}_{\mathrm{o}}\right)$ which states there was no positive influence on madrasa culture $\left(\mathrm{X}_{3}\right)$ on teacher performance $(\mathrm{Y})$ against alternative hypotheses $(\mathrm{Ha})$ which stated there was a positive influence, the test using techniques multiple regression analysis. Hypothesis test results showed that tcount was obtained at 3.226 and the significance value (Sig.) 0.002. Thus, Ho is rejected and Hi is accepted, which means that there is a positive and significant influence of madrasa culture on teacher performance. The magnitude of influence is shown by the coefficient of determination $R 2$ ( $R$ square) $=0,423$, which means that madrasa culture gives an influence on teacher performance by $42.3 \%$ and the remaining $57.7 \%$ is determined by other factors.

The results of the study show the statistical influence of motivation on teacher performance based on the null hypothesis $\left(\mathrm{H}_{\mathrm{o}}\right)$ which states there is no positive influence between the leadership of the madrasah head $\left(\mathrm{X}_{1}\right)$ and motivation $\left(\mathrm{X}_{2}\right)$ on teacher 
performance (Y) against the alternative hypothesis (Ha) which states there is a positive influence, the test uses multiple regression analysis techniques. Hypothesis test results showed that $t$ counts were 4,690 and 2,567, the significance values (Sig.) Were 0,000 and 0.012. Thus, $\mathrm{H}_{\mathrm{o}}$ is rejected and $\mathrm{Hi}$ is accepted, which means that there is a positive and significant influence between the leadership of the madrasah head and motivation on teacher performance. The magnitude of influence is indicated by the coefficient of determination R2 ( $\mathrm{R}$ square $)=0,488$, which means that the madrasah head leadership and motivation influence the performance of teachers by $48.8 \%$ and the remaining $51.2 \%$ is determined by other factors.

\section{Conclusion}

1. There is a positive and significant influence between the leadership of the madrasa head on teacher performance. The magnitude of influence is indicated by the coefficient of determination R2 (R Square) $=0.350$, which means that the leadership of the madrasah head gives influence on teacher performance by $35 \%$ and the remaining $65 \%$ is determined by other factors. The results of a simple regression analysis show the regression equation (unstandardized coefficients $\mathrm{B}$ ) $\hat{\mathrm{Y}}=30.533+0.300 \mathrm{X}_{1}$, which means that each increase in one unit of madrasah head leadership score will be followed by an increase in teacher performance scores of 0.300 .

2. There is a positive and significant effect between motivation on teacher performance. The magnitude of the effect is shown by the coefficient of determination $\mathrm{R} 2$ ( $\mathrm{R}$ square) = 0.236 , which means that motivation influences teacher performance by $23.6 \%$ and the remaining $76.4 \%$ is determined by other factors. The results of a simple regression analysis show the regression equation (unstandardized coefficients $\mathrm{B}$ ) $\hat{\mathrm{Y}}=30.533+0.218$ $\mathrm{X}_{2}$, which means that each increase in one unit of motivation scores will be followed by an increase in teacher performance scores of 0.218 .

3. There is a positive and significant influence between madrasa culture on teacher performance. The magnitude of influence is shown by the coefficient of determination R2 ( $\mathrm{R}$ square $)=0,423$, which means that madrasa culture gives an influence on teacher performance by $42.3 \%$ and the remaining $57.7 \%$ is determined by other factors. The results of a simple regression analysis show the regression equation (unstandardized coefficients B) $\hat{Y}=30.533+0.270 \mathrm{X} 3$, which means that each increase in one unit of madrasa culture scores will be followed by an increase in teacher performance scores of 0.270 .

4. There is a positive and significant influence between madrasah head leadership and motivation on teacher performance. The magnitude of influence is indicated by the coefficient of determination $\mathrm{R} 2$ ( $\mathrm{R}$ square) $=0,488$, which means that the madrasah head leadership and motivation influence the performance of teachers by $48.8 \%$ and the remaining $51.2 \%$ is determined by other factors. The results of a simple regression analysis show the regression equation (unstandardized coefficients $\mathrm{B}$ ) $\hat{\mathrm{Y}}=30.533+$ $0.300 \mathrm{X} 1+0.218 \mathrm{X}_{2}$, which means that each increase in one unit of madrasah head leadership score and motivation will be followed by an increase in teacher performance scores by 0.518 . 


\section{References}

Abdillah and A. Sulaiman. (2019). The contribution of work motivation and Communication toward teachers' Performance at Muhammadiyah 02 Tanjung sari medan. Managere: Indonesian Journal of Educational Management. Vol. 01 No. 01, p. 99-111.

Arif, S. et al. (2019). Influence of Leadership, Organizational Culture, Work Motivation, and Job Satisfaction of Performance Principles of Senior High School in Medan City. Budapest International Research and Critics Institute-Journal (BIRCI-Journal). P. 239254

Gibson, Ivanevich dan Donelly. (1996).Organization Behaviour Struktur Proses, Penerjemah Djarkaisih. Jakarta: Erlangga,1996,52.

Kusumastuti,Dyah. (2001). Manajemen Sistem Pengembangan Sumber Daya Dosen Sebagai Penjamin Mutu Di Perguruan Tinggi, Studi Tentang Pengaruh Kompetensi Individu Terhadap Kinerja Dosen Yang Berotientasi Pada Mutu Dengan Moderator Iklim Organisasi Dan Dukungan Sumber Daya Di Institut Tekhnologi Bandung (ITB) . Disertasi Doktor Pada PPS Universitas Pendidikan Indonesia: tidak di terbitkan.Mulyasa, 2012. Manajemen Dan Kepemimpinan Kepala Sekolah Dasar. Jakarta: Bumi Aksara.

Nawawi, H. Hadari.(2001). Administrasi Pendidikan.Yogyakarta: Gadjah Mada

Robbins, Stephen P. (2006). Organizational Behavior: Concepts, Controversies, Applications. San Diego: Prentice Hall International, Inc.

Siagian, Sondang P.(2002). Manajemen Sumber Daya Manusia. Jakarta:Bumi Aksara

Siahaan, Amiruddin Dan Bayoangin, Tohar. (2014). Manajemen Pengembangan Profesi Guru. Bandung:Citapustaka Media.University Press.

Supardi. (2013). Kinerja Guru.Jakarta: PT.Raja Grafindo Persada.

Stewart L.Tubbs, Sylvia Moss. (2005). Human Communication. Bandung: Remaja Rosdakarya.

Wahjosumidjo.(2001). Kepemimpinan Kepala sekolah Tinjauan Teoritik Dan Permasalahannya, Jakarta: Rajawali Pers.

Wahyudi. (2009). Kepemimpinan Kepala Sekolah Dalam Organisasi Pembelajar (Learning Organization).Bandung: Alfabeta. 